\title{
The Nuances of Active Learning Model in English for Professional Nurses
}

\author{
Deddy Suryana*, Amanda Puspanditaning Sejati, Agus Suherman \\ Universitas Pendidikan Indonesia \\ *Corresponding author. Email: deddysuryana88@upi.edu
}

\begin{abstract}
Achieving the purpose of learning is one of the objectives of education implementation. Learning models selection that suit the learning objectives and students' characteristics can be a contributing factor to learning goal achievement. One of the learning models that is in line with Merdeka Belajar-Kampus Merdeka policy applied in Indonesia is the Active Learning model. This research aims to illustrate the implementation of active learning models in English learning for professional nurses and students' responses. The research subjects were 1 lecturer and 138 nursing students. Data analysed were learning activities, learning documents, as well as perceptions of lecturer and students. The data was taken by using observations, interviews, document studies, and questionnaires. The results of this study include active learning models that can be applied to synchronous and asynchronous methods through activities that trigger the role of students to be more involved in learning; and student responses related to aspects in learning is quite high i.e., lecturer's effectiveness aspect was 4.01, the attitude of students was 4.04, and the availability of learning resources was 3.98. This research is expected to provide an overview for education organizers in developing active learning models at higher education level.
\end{abstract}

Keywords: Active Learning, English for Professional Nurses, Learning Model

\section{INTRODUCTION}

Learning is defined as a goal-oriented planned activity. The products expected from this learning include the creation of creative and innovative people (Print \& Lange, 2012). In the context of higher education, learning aims to shape humans to be able to contribute to society through their critical thinking, not just being ready to work (Rawlinson \& Dewhurst, 2013). In the realm of formal education, these objectives are described in Learning Outcomes which refer to a series of competencies possessed by graduates.

One of the options that can be taken to achieve the optimum learning objectives is to actively involve students in building their knowledge (Illeris, 2007; Sheafer, 2017). Student involvement should be established as students are required to be able to interact with the environment, so that learning tends to be meaningful when compared to teacher-centered learning (Lokse, Lag, Solberg, Andreassen, \& Stenersen, 2017; Todd, 2010). The student-centered learning model is called the Active Learning model, since learning activities are dominated by students (Lokse et al., 2017). This concept is in line with the Merdeka Belajar Merdeka Kampus policy promoted by the Minister of Education and Culture of Indonesia which is the embodiment of student-centered learning (Directorate General of Higher Education, Ministry of Education and Culture, 2020).

The advantage of this learning model lies in the meaning of learning for students [8]. Even though it is considered a modern learning model, it has shortcomings, including requiring more time and supporting facilities (Goetze, 2015; Roman, 2014). Active Learning model is an eminent learning model; hence it is recommended to be implemented especially at the higher education level (Lewis \& Harrison, 2012) and in the context of post-modern education where the participants are the millennial generation (Roman, 2014). More specifically, this learning model is recommended in health education at the higher education level. 
These recommendations are motivated by health students' needs, in this context, including medical and nursing students. They require some experience in interacting with real learning sources, such as patients and the community. In addition, they also need to be involved in the experience of accessing and using information that can enrich their scientific studies. These learning experiences can be facilitated by implementing Active Learning model (Michael \& Modell, 2003)

Some of the results of studies regarding the implementation of the Active Learning model that have been documented include the use of Active Learning model which can improve teacher professional competence (Bergh, Ros, \& Beijaard, 2014); can improve students' understanding of social science studies (Corey, 2010; LaCosse et al., 2017); can improve students' entrepreneurial skills (Amir \& Suryana, 2018); can increase students' political awareness (Archer \& Miller, 2011); and can improve clinical competence of nursing students (Hoke \& Robbins, 2005). A number of these studies confirm the positive benefits of using the Active Learning model.

Based on the review of several previous studies above, the study of the benefits of using the Active Learning model in subjects related to developing language competencies in health students has not been described. Therefore, this study aims to explore the implementation of Active Learning model in English for Professional Nurses subject at the nursing study program, along with the responses of students who went through this active learning model. The results of this study are expected to be a reference for the implementation of active learning at the higher education level.

\section{METHOD}

This study used a descriptive research design with a qualitative approach. The choice of this method refers to the purpose of this study which is to describe a social phenomenon in form of learning activities. Broadly speaking, descriptive research is a research that aims to describe phenomena, circumstances, perceptions, individual traits, and the spread of symptoms (Silverman, 2005). In addition, the data analysed in this study were in form of documents and perceptions. This data applied to be qualitative since it is in the form of categories or words (Somantri \& Muhidin, 2011). Therefore, the use of descriptive research methods by employing a qualitative approach is considered appropriate as the method used in this study.
The subjects of this study were students and a lecturer in the nursing study program. The population involved was 138 students of the fourth semester in related study programs and 1 lecturer who teaches English for Professional Nurses subject and learning process documents. The data and collection techniques employed in this study were learning activities taken by using observation and interviews, learning documents were taken by using a document study, and student perceptions were taken by using a questionnaire.

The questionnaire used consists of a number of statements that aim to explore the aspects contained in the learning environment. The choice of this aspect is due to the fact that learning usually depends on 3 aspects, namely the effectiveness of lecturers in helping the student learning process, student attitudes that reflect responsible learners, and the availability of learning resources (Michael \& Modell, 2003). Therefore, these three aspects were used as a guide for drafting questionnaires. In addition, the statements in the questionnaire were adapted from a sample questionnaire made by Michael \& Modell (2003) contained in his book discussing the Active Learning model (Michael \& Modell, 2003). The statements in this questionnaire have been modified by being converted into Indonesian to match the language used by respondents. This modification aims to improve respondents' understanding of the aspects asked. However, this questionnaire instrument has not gone through a validity test due to time constraints that do not allow finding respondents for validity test. This test is necessary to find an instrument that is suitable for respondents i.e., nursing students in Indonesia.

The effectiveness aspect of lecturer in assisting the student learning process is reflected in 14 statements (114). Furthermore, aspects of the student's attitude describing his or her role as a responsible learner are illustrated in 15 statements (15-29). The next aspect is the availability of learning resources, expressed in 6 statements (30-35). Each statement submitted requires a response measured using the Likert scale. The scale range used is from number 1 which describes Strongly Disagree opinion to number 5 which reflects Strongly Agree opinion. Data in the form of responses related to aspects in learning is analysed using descriptive statistics to see the level of each aspect. The level is juxtaposed with the Likert scale of number 1 (Strongly Disagree) which indicates the Low level, and number 5 (Strongly Agree) indicating the High level. This categorization can be seen in table 1 . 
Table 1. Category of perception and level of aspects in learning

\begin{tabular}{ccc}
\hline Score & $\begin{array}{c}\text { Perception on } \\
\text { Aspects in } \\
\text { Learning }\end{array}$ & $\begin{array}{c}\text { Achievement } \\
\text { Level Aspects in } \\
\text { Learning }\end{array}$ \\
\hline 1 & Strongly Disagree & Low \\
2 & $\mid$ & $\mid$ \\
3 & & $\mid$ \\
4 & & High \\
5 & \multicolumn{2}{|c}{ Strongly Agree }
\end{tabular}

\section{RESULTS AND DISCUSSION}

\subsection{Active Learning Model Implementation}

Based on the data from the interviews with the lecturer, the implementation of Active Learning model in English for Professional Nurses subject aims to enable students to master the ability to use English to carry out nursing care, health promotion, and describe issues related to nursing science.

One way to realize the above goals is to facilitate students with a conducive learning environment. A conducive and safe learning environment is important since these situations can foster student motivation to learn (Michael \& Modell, 2003). Connecting to this, the lecturer who applies Active Learning model in English for Professional Nurses subject made several efforts to create a safe learning environment, including facilitating students to practice in the classroom and outside the classroom which is done both directly and online; provided opportunities for students to explore the material independently, and facilitate students to carry out discussions in small groups online. The learning conditions in the even semester of the 2019/2020 school year is said to be special conditions because half of the learning process was carried out during the COVID-19 pandemic.

Other learning experiences offered by the lecturer who teaches related subjects include three main things. First, providing the student experience of learning by listening. In this context, students are directed to listen to the presentation of the group assigned to present a topic per meeting. Second, the experience of learning through seeing. In this case, students are invited to see the use of language in the nursing context which is presented in English-language videos and films of a nursing context. Third, students are asked to practice communication in the nursing context for the purpose of nursing care and health promotion. The learning activities are in line with the active learning principle of focusing on student engagement and building understanding through group learning activities [20]. In connection with this, Chen and Lin (2020) emphasized that learning that emphasizes the active role of students in the group can improve the reach of learning goals. This is in line with Benek-Rivera and Mathews (2004) who states that active learning can motivate students to be actively involved in their group. Based on the results of the interview, active learning can be used to train the ability to work together in teams. This ability is needed by nurses when dealing with patients to provide nursing care.

The next presentation is the result of data analysis which was collected by employing observation techniques. Observation is focused on matters related to the characteristics of the learning situation and the techniques used to facilitate the creation of active learning situations. The explanation is as follows.

The choice of learning model is one aspect that has to be decided by the lecturer before starting the lecture process. In this study, the Active Learning model was a model chosen by the lecturer to present English for Professional Nurses subject. The selection of active learning models in this course is motivated by learning achievements that require students to master the skills that can be achieved through simulation (Cevik et al., 2016). The active Learning model has several characteristics, including learning activities dominated by students, the instruction given by the lecturer emphasizes on strengthening student abilities, students are trained to develop complex thinking skills, students are involved in-class activities, and students explore the attitudes and values they learn (Smart \& Csapo, 2007).

Based on the observations that have been made, these five characteristics appeared in the lecture situation of the English for Professional Nurses subject at the Nursing Study Program. The first characteristic was that students seem to dominate, especially in the discussion and presentation sessions. The second characteristic is that student-oriented that sees the students as a source of information rather than just a processor of exchanging information sourced from lecturers. In this context, students were assigned to independently find additional sources of information related to language use in nursing contexts. The third characteristic is that students were given the opportunity to process and apply the knowledge they have acquired by simulating the provision of nursing care and health promotion using English. The fourth characteristic is the involvement of students in-class activities in form of writing, reading, listening, and discussing. The fifth 
characteristic is the activity of exploring attitudes and values carried out by students. In this context, students were assigned a peer assessment of the student's presentation and video simulation. These learning activities are carried out both conventionally and distance learning by using synchronous and asynchronous methods. This shows that active learning can be implemented both in the classroom and in learning using technology media (Nicol, Owens, Le Coze, MacIntyre, \& Eastwood, 2018) The emergence of these five active learning characteristics seems to confirm that this learning model can be implemented in nursing students. In general, the learning activities studied in this study highlight student engagement, cooperation between students, experience creating, and interaction in the community (Reinschmidt, Maez, Iuliano, \& Nigon, 2019)

Subsequent observations were made by using document study techniques. This technique is used to examine things in the form of the order in which the material is delivered and the appearance of active learning characteristics in related documents (RPS). Based on the results of observations, the order of the material presented is in accordance with what was stated in the RPS. In addition, one of the characteristics of learning conveyed using the Active Learning model is to hone complex cognitive thinking skills by referring to Bloom's taxonomy (Michael \&Modell, 2003) Based on document studies on RPS of the subject matters, there were variations in cognitive levels that dominate $\mathrm{C}$, $\mathrm{C} 4, \mathrm{C} 5$, and $\mathrm{C} 6$. A number of cognitive variations were spread across all meetings consisting of 14 meetings. Honing the abilities of high-level cognitive in this context aims to encourage students to be involved both physically and mentally (Wright, Bergom, \& Bartholomew, 2019). This is in line with the active learning objectives that carry the principle of constructivism learning to make students well trained in problem-solving and critical thinking (Franco \& DeLuca, 2019).

\subsection{Students' Responses}

Further observations were made to explore student responses to the use of Active Learning model in English for Professional Nurses subject at the Nursing Study Program. Data in the form of these perceptions were taken by employing a questionnaire technique. Michael \& Modell (2003) state that there are 3 aspects that affect learning i.e., the effectiveness of the lecturer in helping student learning processes, student attitudes that reflect responsible learners, and the availability of learning resources. Therefore, the questionnaire presented to students aims to explore these three aspects as measured by a Likert scale with a scale ranging from 1 (Strongly Disagree) to 5 (Strongly Agree). The number is juxtaposed with the level of achievement of that aspect in which number 1 shows Low and number 5 indicates High.

The questionnaire was distributed to 138 students who were taken by using the total population sampling technique. However, the total number of students who filled out the questionnaire was only 125 students. Based on the data analysis, the value distribution of the three explored aspects can be seen in Table 2.

Table 2. Distribution of learning aspects value

\begin{tabular}{clc}
\hline No. & \multicolumn{1}{c}{ Aspects } & Values \\
\hline 1. & $\begin{array}{l}\text { Lecturer } \\
\text { effectiveness }\end{array}$ & 4.01 \\
2. & $\begin{array}{l}\text { Student attitude } \\
\text { 3. }\end{array}$ & $\begin{array}{l}\text { Learning resources } \\
\text { availability }\end{array}$ \\
\hline
\end{tabular}

Based on the information in table 2, the aspect of lecturer effectiveness in delivering material has a value of 4.01. This high value can be triggered by the efforts of a lecturer to design learning experiences that are relevant to the achievement indicators listed in the RPS. In addition, the task of making nursing care simulation videos and health promotion is thought to be a trigger that improves students' abilities in terms of nursing theory and practice. Figures 4.01 in this aspect shows that students feel the effectiveness of lecturers in delivering materials is arguably to be High.

The second aspect that is observed through the questionnaire technique is the aspect of student attitudes towards their responsibilities as students. This aspect has a value of 4.04 which shows the attitude of students in learning may regard to be High. The high value of this aspect can indicate student awareness of their responsibility to learn, especially to learn the skills needed by nurses. In addition, the high awareness of students to learn was triggered by the material presented that is an authentic experience that comes from witnessing and simulating the provision of nursing care and health promotion. The high level of this aspect can be due to the active role of students in the learning process. This is in accordance with the purpose of active learning at the higher education level, i.e., to make learning for adults who tend to be passive become more active (Roberts, 2019). The third aspect explored was the aspect of the availability of learning resources. This aspect has a value of 3.98. This value is high as the highest value on the Likert scale used is 5 (Strongly 
Agree) and shows the level of achievement that can be said to be High. This high value came up from the impact of learning activities in form of discussions and independent exercises, which provide opportunities for students to learn from other people's experiences and from themselves.

\section{CONCLUSION}

The results of this research show that active learning model can be implemented in the context of learning English for Specific Purposes i.e. English for Professional Nurses subject. Moreover, Active Learning Model can also be applied in synchronous and asynchronous teaching and learning processes, so that it can be implemented in distance learning during the COVID-19 pandemic. The Active Learning Model which is implemented in English for Professional Nurses subject in the related study program has implemented the principles of Active Learning i.e. the effectiveness of lecturer in assisting the student learning process, student attitudes that reflect responsible learners, and the availability of learning resources. In addition, conclusions related to student responses show that aspects of learning presented using active learning have a high level of achievement. The high achievement of aspects in learning indicates that students feel that materials delivery presented by lecturers tends to be effective in accordance with the target of learning achievement, students tend to have a responsible attitude in learning, and students feel that the available learning resources are considered capable to support the learning process.

The results of this study are expected to provide an overview of the implementation of active learning in nursing education. The Limitations of data collection found when the data were taken through observation that cannot be done directly due to the COVID-19 pandemic, so the data in the form of student learning environment cannot be explored to the maximum. Limitations related to data analysis is that the data in this study is only analysed using descriptive statistics, so to get a more comprehensive conclusion other data analysis techniques are needed, and the use of instruments in the form of questionnaires that are converted into Indonesian language has not gone through a validity test. In addition, higher education should be able to develop and recommend the use of active learning to increase opportunities for learning. In addition, lecturers are expected to implement the principles of active learning in various subjects both in theories and practices.

\section{REFERENCES}

Amir \& Suryana, D. (2018). Active learning teaching and learning model of Entrepreneurship subject at English Education program of Indonesia University of Education. Lembaran Ilmu Kependidikan, 47(1), $1-7$.

Archer, C. C., \& Miller, M. K. (2011). Prioritizing active learning: an exploration of gateway courses in political science. The Teacher, 429-434. https://doi.org/10.1017/s1049096511000291

Benek-Rivera, J., Mathews, V.E.(2004). Active learning with jeopardy: students ask the questions. Journal of Management Education, vol. 28, 104-118. https://doi.org/10.1177/1052562903252637

Bergh, L. V., Ros, A., \& Beijaard, D. (2014). Improving teacher feedback during active learning: effects of a professional development program. American Educational Research Journal , 51(4), 772-809. https://doi.org/10.3102/0002831214531322

Cevik, M., Ergun, M. A., Stout, N. A., Trentham-Dietz, Craven, M,. \& Alagoz, O,. (2016). Using active learning for speeding up calibration in simulation models. Medical Decision Making, 36(5), 581-593. https://doi.org/10.1177/0272989X15611359

Chen, J., Lin, T. F. (2020). Do cooperative-based learning groups help students learn microeconomics?, SAGE Open, 10(3). https://doi.org/10.1177/2158244020938699

Corey, S. H. (2010). Pedagogy and place: merging urban and environmental history with active learning. Journal of Urban History, 36(1), $28-41$. https://doi.org/10.1177/0096144209349882

Franco, P. F., \& DeLuca, D. A. (2019). Learning through action: Creating and implementing a strategy game to foster innovative thinking in higher education. Simulation \& Gaming, 50(1), 2343. https://doi.org/10.1177\%2F1046878118820892

Goetze, D. (2015). Hybrid active learning situations: common pools, climate change and course purposes. Simulation \& Gaming, 46(6), 792-816. https://doi.org/10.1177/1046878115620089

Hoke, M. M., \& Robbins, L. K. (2005). The impact of active learning on nursing students' clinical success. Journal of Holistic Nursing, 23(3), 348355. https://doi.org/10.1177/0898010105277648

Illeris, K. (2007). What do we actually mean by experiential learning? Human Resource Development Review, 6(1), 84-95 https://doi.org/10.1177/1534484306296828

LaCosse, J., Ainsworth, S. E., Shepherd, M. A., Ent, M., Klein, K. M., L., H.-C., . . . Licht, B. (2017). An 
Active-Learning Approach to Fostering Understanding of Research Methods in Large Classes. Teaching of Psychology, 44(2), 117-123. https://doi.org/10.1177/0098628317692614

Lewis, S., \& Harrison, M. A. (2012). Online delivery as a course adjunct promotes active learning and student success. Teaching of Psychology, 39(1), 7276. https://doi.org/10.1177/0098628311430641

Lokse, M., Lag, T., Solberg, M., Andreassen, H. N., \& Stenersen, M. (2017). Teaching information literacy in higher education. Cambridge: Chandos Publishing.

Nicol, A. A,. Owens, S. M., Le Coze, S. S., MacIntyre, A., \& Eastwood, C. (2018). Comparison of hightechnology active learning and low-technology active learning classrooms. Active Learning in Higher Education, 19(3), 253-265. https://doi.org/10.1177/1469787417731176

Michael, J. A. \& Modell, H. I., (2003). Active learning in secondary and college science classrooms: a working model for helping the learner to learn. London: Lawrence Erlbaum Associates Publishers.

Print, M., \& Lange, D. (2012). Schools, curriculum and civic education for building democratic citizens. Rotterdam: Sense Publishers.

Rawlinson, S., \& Dewhurst, P. (2013). How can effective university-industry partnerships be developed? Worldwide Hospitality and Tourism Themes, 5(3), 255-267. https://doi.org/10.1108/WHATT-02-2013-0004

Reinschmidt, K. M., Maez, P., Iuliano, J. E., Nigon, B. M. (2019) Using active learning strategies linked to CBPR principles in a semester-long class project to teach qualitative research methods in public health. Pedagogy in Health Promotion, 5(1), 36-44. https://doi.org/10.1177/2373379918761976

Roberts, D. (2019). Higher education lectures: From passive to active learning via imagery? Active Learning in Higher Education, 20(1), 63-77. https://doi.org/10.1177/1469787417731198

Roman, A. F. (2014). Methods of designing integrated learning. Journal Plus Education, 11(2), 31-36.

Sheafer, V. (2017). Using digital storytelling to teach psychology: a preliminary investigation. Psychology Learning \& Teaching, 16(1), 133-143. https://doi.org/10.1177\%2F1475725716685537

Silverman, D. (2005). Doing qualitative research a practical handbook (2nd ed.). London: Sage Publications.

Smart, K. L., \& Csap, N. (2007). Learning by doing: Engaging students through learner-centered activities. Business and Professional
Communication Quarterly, 70(4). 451-457 https://doi.org/10.1177\%2F1080569907070004030 2

Somantri, A., \& Muhidin, S. A. (2011). Aplikasi statistika dalam penelitian. Bandung: Pustaka Setia.

Todd, R. J. (2010). Curriculum integration: Learning in a changing world. Australia: ACER Press.

Wright, W. C., Bergom, I., Bartholomew, T. (2019). Decreased class size, increased active learning? Intended and enacted teaching strategies in smaller classes. Active Learning in Higher Education, 20(1), 51-62. https://doi.org/10.1177/1469787417735607 